\title{
Estimation of Discretionary Fuel for Airline Operations
}

\author{
Hyoseok Chang"
}

\begin{abstract}
Fuel costs represent one of the most substantial expenses for airlines, accounting for $20 \%$ $36 \%$ of the airline's total operating cost. The present study discusses the so-called discretionary fuel that is additionally loaded at the discretion of airlines to cover unforeseen variations from the planned flight operations. The proper range of the discretionary fuel to be loaded for economic flight operations was estimated by applying Monte Carlo simulation technique. With this simulation model for loading discretionary fuel, airlines cannot only reduce the total amount of fuel to be consumed but also minimize the risk of unplanned flight disruptions caused by insufficient fuel on board. Airlines should be able to guarantee proper risk management processes for fuel boarding by carrying enough fuel to high-risk airports. This study would provide a practical guideline for loading proper amounts of discretionary fuel. Future researchers should be encouraged to improve this study by elaborating the weather variable.
\end{abstract}

Key Words : Fuel Cost(연료비), Fuel Consumption(연료소모량), Monte Carlo Simulation(몬테카를 로시뮬레이션), Discretionary Fuel(재량연료량)

\section{INTRODUCTION}

Oil price has risen since the late 1990s owing to decline in OPEC's crude oil production. With funds raised through rising oil prices, airlines from the Gulf Cooperation Council Countries aggressively competed in the market. They purchased a large number of aircraft and increased their seat capacity, which in turn contributed to a steady increase in jet fuel price.

Jet fuel price, in 2008, soared five times higher than that of early $2000^{1)}$ due to increase in the demand for crude caused by the expanded supply in the Middle East and the increased

Received: 28. Dec. 2020, Revised: 18. Mar. 2021,

Accepted: 20. Apr. 2021

* 한서대학교 항공교통물류학과 교수

연락저자 E-mail : daniel.chang@hanseo.ac.kr

연락저자 주소 : 충청남도 태안군 남면 곰섬로 236-49 number of LCCs worldwide.

According to CAPA(Centre for Asia Pacific Aviation), fuel costs represent one of the most substantial expenses for airlines, accounting for $20 \%-36 \%$ of the airline's total operating cost, although the recent decline in the oil price has increased the labor cost's proportion of the airline's operating cost. Given that the oil price is influenced by political, economic, and social factors, it is difficult to estimate the fuel cost. However, it is possible to reduce the fuel cost by improving the understanding of aircraft fuel burn. Conventional fossil-based jet fuel consumption is an important factor from not only the economic perspective but also the environmental perspective, in that it directly contributes

1) U.S. Gulf Coast Kerosene-Type Jet Fuel Spot Price FOB, U.S Energy Information Administration, https://www.eia.gov/dnav/pet/hist/LeafHa ndler.ashx?n=pet\&s=eer_epjk_pf4_rgc_dpg\&f=m 
to the greenhouse gas effect. Airlines need to deal with manifold market-based measures that might be utilized to reduce carbon dioxide emissions. According to International Air Transport Association (IATA) (2013), in terms of fuel efficiency relative to the world's fuel price, attention to fuel economy differs directly with the cost of fuel. That is, the fuel efficiency becomes the main topic of discussion only when the oil price goes up, but otherwise, it draws less attention.

Nonetheless, fuel has traditionally been one of the core considerations for operational efficiency and emission reduction. However, airlines cannot just reduce the total amount of fuel to be loaded only on economic grounds because they should comply with the regulations stipulating the minimum fuel requirements. For a commercial flight, the standard fuel load includes trip fuel, alternate fuel (if required), contingency fuel, and final reserve fuel.

For the safety of operation, airlines apply their fuel policies such as discretionary fuel. This study discusses the so-called discretionary fuel, which is additionally loaded at the discretion of airlines to cover unforeseen variations from the planned flight operations such as adverse weather conditions and airport congestion.

Most full-service carriers have implemented fuel conservation programs since the early 2000s to improve their profitability. The airline dispatchers calculate the flight time along with fuel requirements and file the ATC flight plan.

A dispatcher is a qualified person who is responsible for the safety of the flight, monitors the progress of the flight, and provides the pilot with any irregularities of airport facilities and additional information of weather conditions that might affect the flight operations. Therefore, airlines should ensure that dispatchers are adequately trained to perform their duties and responsibilities. The dispatcher should evaluate or consider the weather conditions when selecting a route. If adverse weather condition such as thunderstorms, turbulence, or typhoon is expected to affect the flights, dispatchers should analyze the situation and select a route other than the normal ones. They also have to collect and analyze information that has the potential to affect the flight, including the passenger and cargo weights and aircraft take-off and landing performance.

They must be well aware of the flight release procedures. Accurate flight plan calculations can reduce airline operating costs by selecting the optimal route, altitude, and speed as critical tasks for safe operation (Altus, 2009).

In the case of Korean full-service carrier, authorized dispatchers are responsible for both domestic and international operations. International operations are further grouped into the continents of Asia, Oceania, Europe, North America, South America, and Africa. The dispatchers are assigned to different desks, based on their level of skills and experience. They are required to prepare a dispatch release for their flights. Those who have less than 5 years of experience may be responsible for the shorthaul flights such as those between the Korea and Asia routes. As they gain experience, their responsibilities will expand to longer flights such as those between the Korea and Europe or America routes.

Thanks to the technological development, the dispatchers' scope of work has expanded beyond the flight plan preparation. In general, the dispatchers prepare the flight plan two hours before the estimated departure time for domestic flights and three hours before for international flights. Flight operations are complicated with various considerations including mechanical, technological, and weather conditions.

Dispatchers must make amends to the original flight plan when mechanical problems arise, aircraft and equipment has changed, weather conditions have changed, and so on, since the time of filing the original flight plan. 
Dorneich (2003), through an in depth interview with flight dispatchers, analyzed that it only takes about 2 to 3 minutes to physically prepare flight plans if the weather conditions at departure, arrival, and en route are suitable for flight operations. However, it takes about 30 minutes to do so when various factors affecting the flight operations need to be reviewed in depth.

\subsection{Purpose of the Paper}

The airlines should comply with the fuel loading requirements of the civil aviation regulations by the standards and recommendations stipulated by the International Civil Aviation Organization (ICAO).

Airlines should consider various factors, such as safe and economic factors, when establishing their fuel policy. However, airlines tend to load so-called discretionary fuel in addition to the minimum required fuel for take-off on the ground of safe flight operations. Airlines define its discretionary fuel as an amount of extra fuel to be loaded at the discretion of the pilot-in-command and dispatcher from Flight Planning and Fuel Management Manual by ICAO Doc. 9976. After the aircraft arrives at the destination airport, the discretionary fuel usually remains in the tank, unused, resulting in unnecessary fuel consumption. Airlines tend to load additional fuel to avoid any potential risk to their flights, which in turn causes the increase in fuel cost that occupies one of the most considerable portions of the airlines' operating cost. Of course, if an airline uplifts the minimum amount of fuel legally required for take-off without considering the adverse weather conditions at the destination airport, there is a greater chance of a diversion to an alternative airport. Therefore, it is very critical to analyze the fuel requirements based on the statistics by considering various factors to minimize the irregular operations while decreasing the fuel cost.

Carrying excessive amount of discretionary fuel results in additional fuel burn for the additional fuel cost and carbon emission. Therefore, accurate flight planning through extensive analysis of fuel consumption is required.

Various factors affecting fuel consumption during the flight include upper wind, temperature, flight level, aircraft weight, and engine performance. By measuring the deviation between the planned and actual fuel burn, it is possible to estimate the fuel consumption rate by aircraft type and route.

Greenhouse gas emissions from aircraft constitute $9 \%$ of the total transportation sector emissions. ${ }^{2}$ ) Aviation is a small sector but a significant contributor to climate change. Since 2008, greenhouse gas (GHG) emissions have been rising owing to the global economic recovery, and the aviation industry has been working together to reduce carbon emissions. In an effort to prevent global warming, the aviation industry has implemented a carbon neutral program for environmental protection.

The European Union has implemented a market-based carbon emission trading system for the aviation sector since January 1, 2012, which restricts the annual amount of carbon dioxide emissions by airlines operating to and within the EU territory. In addition, the European Union requests to right to purchase in case of emitting more than the stipulated quota. This scheme was applied to the aviation industry in 2013, requesting the airlines to submit their emission data for the flights to and from the European Union to the administering states.

However, 26 countries, including the United States, China, India, and Russia, expressed their official objections against the EU's trading system

2) Environmental Protection Agency 2017 Fast Facts: U.S. Transportation Sector Greenhouse Gas Emissions 1990-2015. 
through the ICAO's dispute procedures. The European Union has proposed "stop the clock" to surrender emission allowance for flights. They have requested a discussion to reduce $\mathrm{CO}_{2}$ emissions in the aviation sector on the ICAO General Assembly. In early 2017, the European Commission issued a draft of emission regulation proposing to extend the application of the emission trading system to the international aviation sector beyond 2016. In October 2016, ICAO member states reached an international agreement to address climate change at the 39th Assembly session and agreed to reduce emissions from 2027 to resolve issues of global GHG emissions.

The purpose of this study is to reduce operating costs and prepare environmental regulations by presenting a methodology for efficient fuel management for airlines.

\subsection{Data for the Paper}

\subsubsection{Aircraft Category and Airport Name}

The ICAO publishes and recommends various guidelines, in the form of Annex, which contains international standards for safety, accuracy, and efficiency. The aircraft type code in this study follows the guidelines presented in DOC 8643 "Aircraft Type Codes" of the ICAO. These codes are the 4-character alphanumeric.

For flights within the flight information region, airlines should file a flight plan to the ATC authorities, including the aircraft type indicated by the ICAO guidelines. Table 1 summarizes the aircraft type analyzed in this study. For the departure and destination airports, the three-letter airport code of the IATA is used.

We collect fuel data of aircraft by destination airport departing from Incheon International Airport (ICN) in 2015. Table 2 presents destination airport city code and airport name.
Table 1. Aircraft type description

\begin{tabular}{c|c}
\hline Aircraft type & Description \\
\hline A333 & Airbus 330-300 \\
\hline A388 & Airbus 380-800 \\
\hline B738 & Boeing 737-800 \\
\hline B773 & Boeing 777-300 \\
\hline
\end{tabular}

Table 2. Destination airport city code and airport name

\begin{tabular}{c|l}
\hline City code & \multicolumn{1}{|c}{ City and airport name } \\
\hline BKK & $\begin{array}{l}\text { Bangkok, Suvarnabhumi International } \\
\text { Airport }\end{array}$ \\
\hline CDG & $\begin{array}{l}\text { Paris, Charles de Gaulle } \\
\text { International Airport }\end{array}$ \\
\hline DPS & $\begin{array}{l}\text { Bali, Ngurah Rai International } \\
\text { Airport }\end{array}$ \\
\hline LAX & Los Angeles International Airport \\
\hline NGO & $\begin{array}{l}\text { Nagoya, Chubu Centrair } \\
\text { International Airport }\end{array}$ \\
\hline NRT & Narita International Airport \\
\hline SIN & $\begin{array}{l}\text { Singapore, Changi International } \\
\text { Airport }\end{array}$ \\
\hline
\end{tabular}

\subsubsection{Fuel Category}

The European Union's Carbon Emissions Trading System and the Korean Greenhouse Gas Emission Trading System state that the airlines shall report carbon emissions to the governments or authorities concerned. The airlines have established their database to collect the fuel consumption data for every stage of the flights to meet their reporting requirements.

The airlines have analyzed this fuel consumption database and sought the reasons why their aircraft consumed more fuel than planned. Moreover, the airline also needs to evaluate differences in fuel burn between planned and actual flights for their fleets and routes.

The fuel requirements are based on the ICAO Doc 9976 "Flight Planning and Fuel 
Management Manual" and the European Aviation Safety Agency Commission Regulation No. 965/ 2012 on air operations. The Federal Aviation Administration also provides its requirement in the Federal Aviation Regulations (FAR) §121.645 "Fuel supply: Turbine-engine powered airplanes, other than turbo propeller: Flag and supplemental operations" and the Korean Ministry of Land, Infrastructure, and Transport No. 2017397 "Flight Safety Regulations for Aeroplanes".

The operational standards for fixed-wing aircraft in Korea stipulate that the fuel consists of taxi fuel, trip fuel, contingency fuel, destination alternative fuel, final reserve fuel, additional fuel and discretionary fuel, statistical contingency fuel, and tanker fuel.

Trip fuel, also called "mission fuel" by U.S. FAR, is the amount of fuel required from the departure airport to the intended destination airport.

Destination alternative fuel is the fuel required from the missed approach point of the destination airport to the alternative airport in case the aircraft is unable to land at the destination airport due to abnormal operational conditions.

Final reserve fuel is the minimum fuel reserved for the pilot to be able to hold the aircraft at $1,500 \mathrm{ft}$ above the alternative airport for 45 minutes.

Contingency fuel is the amount of fuel legally required to compensate for unforeseen circumstances, which is $5 \%$ of the amount of the trip fuel.

Discretionary fuel is extra fuel that is additionally loaded at the discretion of the pilot or dispatcher for dealing with irregular operations such as adverse weather conditions or airport congestion.

According to the ICAO Doc 9976, Statistical Contingency Fuel (SCF) is a flexible fuel loading policy to adjust overburn on specific route and aircraft type based on fuel burn statistics.

If the actual fuel consumption is higher than the planned one for some reason, the additional amount of fuel consumed is calculated and reflected in the next flight plan. Karisch Altus, and StojkovićGand (2012) explain that many operators determine the amount of contingency fuel based on a statistical analysis of the difference between planned and actual fuel consumption on the same route.

Tanker fuel is usually loaded for economic considerations when the fuel prices at the destination and the departure are significantly different, making it less expensive to carry more fuel into the destination than to purchase the fuel there. This method is the purchase of fuel more than that immediately required for the next flight leg, means topping off the tanks at the cheaper stations to the extent the increased burn penalty and station supply allow (Nash, 1981).

The average value of fuel category of City pair and Aircraft type in is listed in Table 3.

The method for calculating discretionary fuel is based on the concept of SCF. Dispatchers have low confidence in applying SCF values due to weaknesses in the current SCF estimation process, so they load more discretionary fuel than is recommended. As a result, enhanced SCF estimation provides another realistic method for lowering discretionary fuel consumption(Kang, 2017). Contingency fuel is never adjusted to what was actually used, so the next flight will still have the same amount. It was not consumption responsive. Some of the city-pairs like congested sections would typically use up all of their contingency fuel. Therefore they need to consider all the different combinations of fleet, path, or city pairs and aircraft type has a different distribution.

Since long-distance sections such as ICNCDG A388 and ICNLAXA388 use the refile procedure, so the amount of contingency fuel is less than 3\% or $5 \%$ described by operations specifications. 
Table 3. Descriptive statistics of the fuel category of city pair and aircraft type

(Unit: Lbs)

\begin{tabular}{l|c|c|c|c|c|c|c|c}
\hline & $\begin{array}{c}\text { Number of } \\
\text { operations }\end{array}$ & $\begin{array}{c}\text { Trip } \\
\text { fuel }\end{array}$ & $\begin{array}{c}\text { Actual fuel } \\
\text { consumption }\end{array}$ & $\begin{array}{c}\text { Contingency } \\
\text { fuel }\end{array}$ & $\begin{array}{c}\text { Destination } \\
\text { alternate } \\
\text { fuel }\end{array}$ & $\begin{array}{c}\text { Final } \\
\text { reserve } \\
\text { fuel }\end{array}$ & $\begin{array}{c}\text { Discre- } \\
\text { tionary fuel }\end{array}$ & $\begin{array}{c}\text { Statistical } \\
\text { contingency } \\
\text { fuel }\end{array}$ \\
\hline ICNBKKA333 & 519 & 68,956 & 67,911 & 2,341 & 4,348 & 5,288 & 4,452 & 920 \\
\hline ICNCDGA388 & 358 & 303,544 & 302,612 & 2,438 & 13,608 & 9,707 & 9,973 & 3,634 \\
\hline ICNDPSA333 & 430 & 83,504 & 83,462 & 3,512 & 16,847 & 4,954 & 8,382 & 1,150 \\
\hline ICNLAXA388 & 720 & 279,740 & 278,145 & 2,083 & 24,113 & 9,796 & 7,624 & 2,881 \\
\hline ICNNGOB738 & 409 & 8,670 & 8,574 & 425 & 4,050 & 3,497 & 2,204 & 503 \\
\hline ICNNRTA333 & 487 & 25,856 & 25,480 & 1,400 & 8,946 & 5,623 & 7,295 & 1,003 \\
\hline ICNSINB773 & 361 & 99,522 & 99,047 & 4,362 & 5,369 & 6,962 & 5,565 & 1,091 \\
\hline
\end{tabular}

Furthermore, only the flights operating every day are selected in this study to avoid possible errors or biases caused by the day of the week.

\subsubsection{Aircraft Fuel Consumption}

The Following studies have reviewed aircraft fuel consumption with aircraft performance data extracted from Lissys PIANO-X software or Euro Control's Base of Aircraft Data (BADA).

PIANO-X is the software that provides analytical tools for gas emissions and operational plan for aircraft. It also provides the database of characteristics of fuel consumption, nitrogen oxide, carbon monoxide, carbon dioxide, drag, and performance by aircraft type.

BADA is the database on the aircraft performance operated by Euro control, which is in charge of air traffic management in Europe, in cooperation with aircraft manufacturers and airlines.

Jensen, Tran, and Hansman (2015) used the speed, altitude, and weight data from the PIANO-X software as input factors to determine differences in aerodynamic parameters and aircraft performance. The flight performance data were compared with the data of BADA to confirm the optimized cruising speed and flight altitude along with the fuel consumption by flight phase. Edwards, Dixon-Hardy, and Wadud
(2016) used the PIANO-X to examine the effect of the cost index on flying time and fuel consumption for different aircraft types.

To estimate the change in fuel consumption by different weight, Ryerson, Hansen, \& Hao (2015) calculated the difference between the predicted fuel consumption data from the PIANO-X and the actual fuel consumption data from the airlines as a percentage. The PIANO$\mathrm{X}$ predicted less than $7 \% \sim 27 \%$.

Wasiuk, Lowenberg, and Shallcross (2015) used the BADA database along with data on global aircraft movements to identify carbon dioxide, carbon monoxide, water, and hydrocarbons.

Pagoni and Psaraki-Kalouptsidi (2017) calculated fuel consumption and $\mathrm{CO}_{2}$ emissions by comparing the clustering and BADA database, reflecting the characteristics of flight based on actual aircraft operational data. This study shows that the clustering method is more accurate than the PIANO-X software data and the BADA database.

This study reveals the relationship between the actual fuel consumption and the discretionary fuel by examining the actual data collected from a Korean full-service carrier. Monte Carlo simulation technique is applied to estimate the proper range of the discretionary fuel to be loaded for economic flight operations for each aircraft type and route. 


\section{MATERIAL AND METHODS}

Monte Carlo simulation method generates data using random numbers when given a problem and approximates the expected results or laws by integrating the results of the manipulations or random experiments. In other words, it is a method of estimating the probability of occurrence by extracting variables at random using several probabilities distributions. It is a probability distribution that defines the possibility that a variable has a value (Dagpunar, 2007; Kalos \& Whitlock 2008). Therefore, if the characteristics of a variable cannot be accurately predicted, the average of the attributes from the probability distributions obtained through repeated observations are taken.

To predict the likelihood of changing the variable, we use the probability model and estimate the parameter. Similarly, we use the variable repeatedly based on the probability model to predict how much the variable will change (Kroese, Thomas, and I., 2011). Since Monte Carlo simulation can consider all the values that the variables can take and reflect the correlation, it can easily analyze various variables and recognize the necessary parameters.

The Monte Carlo simulation supports decision making by generating arbitrary random numbers in the condition of inputs and provides the distributions and statistics of the results in all cases. We use the Monte Carlo simulation methods in various fields such as quantitative risk management, electronics, radiation dose calculation, business risk analysis, quality control, carbon dioxide emission research, pricing of derivatives, forecasting of security value, and prediction of machine reliability.

In the air transport sector, Irvine, Budd, and Pitfield (2015) studied the impact on passengers' inflow to accommodate additional runway construction at the Heathrow, Gatwick, and Stansted airports in London. Pitfield and Jerrard
(1999) adopted Monte Carlo simulation for a new concept of estimating the capacity at Rome Fiumicino International Airport. Stroeve, Blom, and Bert Bakker (2009) studied air traffic control through a systematic evaluation of the Monte Carlo simulation for each scenario on the runway.

In this study, a multiple regression analysis is run to set up an equation model with the actual amount of fuel remaining as the dependent variable. To identify the proper amount of the discretionary fuel based on the model, the probability density function, with the legally required minimum fuel for take-off and the additionally loaded fuel according to company policies, is applied. In addition, the difference between the amount of fuel planned and consumed is added as a variable. Random numbers are generated from the probability density function representing the amount of fuel loaded. A random sample is taken to calculate the appropriate range of the discretionary fuel amount with a 95\% confidence level based on 100,000 repetitions of the process.

We run the SPSS 25.0 statistical software to calculate the amount of discretionary fuel using the Monte Carlo Method.

\subsection{Cost to Carry}

Fuel consumption for a given aircraft is based on various factors such as engine thrust, and aircraft weight is a function of its payload, flight level, aircraft speed, and flying distance.

The IATA defines surplus fuel as a pivotal variable to determine the effects on fuel cost. When the weight increases, the fuel consumption change index concerning the weight change increases by $2.5-5 \%$ of the fuel depending on the aircraft type, distance, flight level, and speed from their study. The fuel cost to carry is calculated by equation where weight increase in the equation is defined as "cost to carry," which depends on aircraft type, flight hours, 
and cost of fuel.

The actual data on the fuel consumption per hour and the landing weight are needed to calculate the "cost-to-carry" factor for weight change.

Even though the cost-to-carry factor can be calculated as a function of the distance, it is estimated as a function of flight hours in this study, as suggested by the IATA.

Table 4 shows the cost-to-carry factor resulting from the regression analysis.

$$
\begin{aligned}
Y= & \beta_{0}+\beta_{1} x_{1}+\beta_{2} x_{2}+\beta_{3} x_{3} \\
& +\beta_{4} x_{4}+\beta_{5} x_{5}
\end{aligned}
$$

where $\mathrm{Y}$ is the actual remained amount of fuel

Table 4. Estimation of cost-to-carry factor

\begin{tabular}{c|c|c}
\hline $\begin{array}{c}\text { City pair and } \\
\text { aircraft type }\end{array}$ & $\begin{array}{c}\text { Cost-to-carry } \\
\text { factor }\end{array}$ & $t$-value \\
\hline ICNBKKA333 & 0.029 & $29.169^{* * *}$ \\
\hline ICNCDGA388 & 0.032 & $17.835^{* * *}$ \\
\hline ICNDPSA333 & 0.031 & $28.597^{* * *}$ \\
\hline ICNLAXA388 & 0.029 & $16.491^{* * *}$ \\
\hline ICNNGOB738 & 0.029 & $10.002^{* *}$ \\
\hline ICNNRTA333 & 0.022 & $12.555^{* * *}$ \\
\hline ICNSINB773 & 0.037 & $27.599^{* *}$ \\
\hline
\end{tabular}

${ }^{*} p<.05,{ }^{* *} p<.01$ (min), $x_{1}$ is the contingency fuel ( $\left.\mathrm{min}\right), x_{2}$ is the destination alternative fuel (min), $x_{3}$ is the final reserve fuel (min), $x_{4}$ is the discretionary fuel (min), and $x_{5}$ is the SCF (min).

\subsection{Monte-Carlo Simulation}

Unless there are irregular operations such as diversion to an alternative airport, aircraft only consume the trip fuel. Theoretically, the aircraft does not consume additionally loaded fuel such as destination alternative fuel, final reserve fuel, and any other fuel loaded as per the company fuel policy. Therefore, the destination alternative fuel, the final reserve fuel, and the reserved fuel loaded according to the company fuel policy will be retained together with the corrected fuel calculated based on the statistic.

We used multivariable regression method to obtain the equation of each fuel category following equation 1. Moreover, Table 5 shows each equation and $R^{2}$.

\section{RESULTS AND DISCUSSION}

Using the regression equation for each aircraft type and destination airport, each probability distribution of the minimum fuel for take-off and the loaded fuel data according

Table 5. Multiple regression equations of fuel category

\begin{tabular}{c|c|c}
\hline $\begin{array}{c}\text { City pair and } \\
\text { aircraft type }\end{array}$ & Equation & $\mathrm{R}^{2}$ \\
\hline ICNBKKA333 & $\mathrm{Y}=-75.079+1.154 \mathrm{X}_{1}+1.076 \mathrm{X}_{2}+3.953 \mathrm{X}_{3}+0.906 \mathrm{X}_{4}+1.432 \mathrm{X}_{5}$ & 0.722 \\
\hline ICNCDGA388 & $\mathrm{Y}=-190.534+0.993 \mathrm{X}_{1}+1.235 \mathrm{X}_{2}+9.599 \mathrm{X}_{3}+0.944 \mathrm{X}_{4}+0.494 \mathrm{X}_{5}$ & 0.899 \\
\hline ICNDPSA333 & $\mathrm{Y}=-85.005+1.042 \mathrm{X}_{1}+1.116 \mathrm{X}_{2}+4.501 \mathrm{X}_{3}+0.964 \mathrm{X}_{4}-0.041 \mathrm{X}_{5}$ & 0.965 \\
\hline ICNLAXA388 & $\mathrm{Y}=-140.510+1.267 \mathrm{X}_{1}+1.134 \mathrm{X}_{2}+7.407 \mathrm{X}_{3}+0.853 \mathrm{X}_{4}+0.193 \mathrm{X}_{5}$ & 0.639 \\
\hline ICNNGOB738 & $\mathrm{Y}=-80.254+2.874 \mathrm{X}_{1}+1.519 \mathrm{X}_{2}+1.339 \mathrm{X}_{3}+0.999 \mathrm{X}_{4}+9.201 \mathrm{X}_{5}$ & 0.971 \\
\hline ICNNRTA333 & $\mathrm{Y}=-97.184+5.702 \mathrm{X}_{1}+1.084 \mathrm{X}_{2}+3.738 \mathrm{X}_{3}+0.985 \mathrm{X}_{4}+1.084 \mathrm{X}_{5}$ & 0.991 \\
\hline ICNSINB773 & $\mathrm{Y}=-245.417+1.196 \mathrm{X}_{1}+1.092 \mathrm{X}_{2}+10.362 \mathrm{X}_{3}+1.021 \mathrm{X}_{4}+3.412 \mathrm{X}_{5}$ & 0.937 \\
\hline
\end{tabular}


to the company policy was populated. In addition, a Monte Carlo simulation was performed to obtain an appropriate range for the discretionary fuel by adding the difference in how much more actual fuel was consumed compared to the trip fuel loaded during each flight.

We used these equations for simulating the range of discretionary fuel. Prior to the simulation, we test the normality of each variable.

The Shapiro-Wilk test was run to examine the normality of each variable before the simulation. The Shapiro-Wilk test is a test of the normality based on the correlation between the data and the corresponding standard scores (Peat and Barton 2005).

Table 6 shows the results. We add the variable $x_{6}$ for the difference between planned trip fuel and actual fuel consumption to simulate discretionary fuel range. The output below the probabilities for every variable is greater than 0.05 , so these data are not different from normal consumption per hour from the Shapiro-wilk test.

Table 7 shows the simulation results, revealing that the average amount of the discretionary fuel loaded is higher than that of the simulation results. In the case of ICN-DPS with Airbus 330-300 (ICNDPSA333 in the table), the average amount of discretionary fuel is about 40 minutes. There was a big volcanic eruption on the main Indonesian island of Java. Owing to the volcanic ash from Mount Raung in the air in July 2015, dispatchers considered more discretionary fuel to ensure flight safety. The simulation result shows that the aircraft have

Table 6. Results of Shapiro-Wilk test

\begin{tabular}{c|c|c|c|c|c|c}
\hline $\begin{array}{c}\text { City pair and } \\
\text { aircraft type }\end{array}$ & $x_{1}$ & $x_{2}$ & $x_{3}$ & $x_{4}$ & $x_{5}$ & $x_{6}$ \\
\hline ICNBKKA333 & 0.279 & 0.193 & 0.076 & 0.096 & 0.211 & 0.102 \\
\hline ICNCDGA388 & 0.381 & 0.429 & 0.074 & 0.174 & 0.222 & 0.066 \\
\hline ICNDPSA333 & 0.317 & 0.268 & 0.051 & 0.260 & 0.458 & 0.115 \\
\hline ICNLAXA388 & 0.339 & 0.212 & 0.054 & 0.145 & 0.295 & 0.169 \\
\hline ICNNGOB738 & 0.206 & 0.139 & 0.067 & 0.179 & 0.076 & 0.116 \\
\hline ICNNRTA333 & 0.238 & 0.384 & 0.377 & 0.219 & 0.378 & 0.322 \\
\hline ICNSINB773 & 0.346 & 0.468 & 0.069 & 0.121 & 0.071 & 0.072 \\
\hline
\end{tabular}

Table 7. Simulations result for discretionary fuel

\begin{tabular}{c|c|c|c}
\hline $\begin{array}{c}\text { City pair and } \\
\text { aircraft type }\end{array}$ & $\begin{array}{c}\text { Average discretionary } \\
\text { fuel }(\mathrm{min})\end{array}$ & $\begin{array}{c}\text { Simulation result } \\
(\mathrm{min})\end{array}$ & The difference (min) \\
\hline ICNBKKA333 & 21.3 & $14.2-14.5$ & $6.8-7.1$ \\
\hline ICNCDGA388 & 22.5 & $20.3-20.7$ & $1.8-2.2$ \\
\hline ICNDPSA333 & 40.1 & $39.1-39.9$ & $0.2-1.0$ \\
\hline ICNLAXA388 & 17.2 & $13.0-13.2$ & $4.0-4.2$ \\
\hline ICNNGOB738 & 22.8 & $21.5-21.9$ & $0.9-1.3$ \\
\hline ICNNRTA333 & 34.9 & $22.3-22.7$ & $12.2-12.6$ \\
\hline ICNSINB773 & 19.9 & $18.1-18.5$ & $1.4-1.8$ \\
\hline
\end{tabular}


consumed most of the discretionary fuel on the flight from ICN to DPS, while the Airbus 330-300 (ICNNRTA333 in the table) from ICN to NRT carried 12.2-12.6 minutes of extra fuel unnecessarily. We believe that dispatchers overestimated the effect of volcanic ash from Hakone Mountain in June 2015 in this city pair.

Table 8 shows the expected amount of the fuel saved and the $\mathrm{CO}_{2}$ emission reduced for each of the seven city-pairs and aircraft type.

To calculate the amount of fuel saved and $\mathrm{CO}_{2}$ reduced, each unit was converted from time to weight by applying the fuel consumption per hour.

According to the Intergovernmental Panel on Climate Change (1999), $\mathrm{CO}_{2}$ emissions are directly proportional to fuel burn (Filippone, 2008) with $3.15 \mathrm{~kg}$ of $\mathrm{CO}_{2}$ emitted for each kilogram of kerosene. It is confirmed that 5,063.6 ton of $\mathrm{CO}_{2}$ can be saved annually from the seven routes. It is expected to save USD 208,896 a year by applying USD 41.25 per ton from the European Energy Exchange as of January, 04, 2021.3)

Table 9 shows the annual cost savings based on equation 1 , with the cost-to-carry factor,

Table 8. Fuel savings and $\mathrm{CO}_{2}$ reduction

\begin{tabular}{c|c|c|c}
\hline $\begin{array}{c}\text { City pair and } \\
\text { aircraft type }\end{array}$ & $\begin{array}{c}\text { Fuel savings per flight } \\
(\mathrm{kg})\end{array}$ & $\begin{array}{c}\mathrm{CO}_{2} \text { reduction per flight } \\
(\mathrm{kg})\end{array}$ & $\begin{array}{c}\mathrm{CO}_{2} \text { annual reduction } \\
(\text { ton })\end{array}$ \\
\hline ICNBKKA333 & 518.7 & $1,634.1$ & 848.1 \\
\hline ICNCDGA388 & 172.5 & 543.4 & 194.5 \\
\hline ICNDPSA333 & 94.2 & 296.9 & 127.7 \\
\hline ICNLAXA388 & 827.3 & $2,606.3$ & $1,876.5$ \\
\hline ICNNGOB738 & 56.5 & 178.2 & $1,682.9$ \\
\hline ICNNRTA333 & $1,097.0$ & $3,455.6$ & 261.0 \\
\hline ICNSINB773 & 229.5 & 723.1 & $5,063.6$ \\
\hline
\end{tabular}

Table 9. Annual cost savings

\begin{tabular}{c|c|c|c|c|c}
\hline $\begin{array}{c}\text { City pair and } \\
\text { aircraft type }\end{array}$ & $\begin{array}{c}\text { Fuel savings per } \\
\text { flight (lb) }\end{array}$ & $\begin{array}{c}\text { Cost-to- } \\
\text { carry factor }\end{array}$ & $\begin{array}{c}\text { Average flying } \\
\text { time }\end{array}$ & $\begin{array}{c}\text { Number of } \\
\text { flight }\end{array}$ & $\begin{array}{c}\text { Annual cost } \\
\text { savings (USD) }\end{array}$ \\
\hline ICNBKKA333 & 3,475 & 0.029 & 5.41 & 519 & 29,606 \\
\hline ICNCDGA388 & 1,156 & 0.032 & 11.37 & 358 & 15,750 \\
\hline ICNDPSA333 & 631 & 0.031 & 6.65 & 430 & 5,853 \\
\hline ICNLAXA388 & 5,543 & 0.029 & 10.45 & 720 & 126,538 \\
\hline ICNNGOB738 & 379 & 0.029 & 1.48 & 409 & 695 \\
\hline ICNNRTA333 & 7,350 & 0.022 & 2.03 & 487 & 16,725 \\
\hline ICNSINB773 & 1,538 & 0.037 & 5.9 & 361 & 12,678 \\
\hline \multicolumn{7}{|c|}{ Total } \\
\hline
\end{tabular}

3) https://www.eex.com/en/market-data/environmental-markets/spot-market, Exchange Rate : 1EUR = 1.21 USD, 04JAN2021 
average flying time, and annual fuel saving. The unit price of fuel is assumed to be US \$2.13 per US gallon (2018.1-2018.8 International average fuel price) from the US Bureau of Transportation statistics. $\left.{ }^{4}\right)$

Fuel savings can be calculated by converting the weight to volume with a density of 6.7 . The simulation shows the annual cost savings of USD 126,538 for the flight from ICN to LAX with A388. If we select this simulation modeling for the discretionary fuel, the airline can save USD 207,845 per year by using this simulation.

Government's environmental regulations drive, such as the EU-ETS, will increase the airlines' burden up to soaring oil price, adding the kind of tax for protecting the environment.

The flight dispatcher has to determine the loading of discretionary fuels on the analysis of historical actual fuel consumption data, except for the minimum required fuel depending on the rules of flight. These discretionary decisions can be optimized using statistical methods and sophisticated predictive tools for data analytics and decision support. Finally, this study assumed that airlines would have the opportunity to reduce operating costs while reducing the cost of purchasing emissions in compliance with government environmental policies through simulation techniques for fuel loading based on statistical calculation method.

\section{CONCLUSION}

Airlines have invested in fuel-efficient aircraft and reduced fuel consumption by avoiding unnecessary items in an effort to reduce fuel costs. Various types of fuel conservation programs have been developed, and fuel consumption has been studied to improve fuel policy. Thanks to the development of the flight planning software, accuracy for fuel planning has improved, thus reducing the difference between the amount of fuel planned and that consumed.

Airlines will be able to ensure that a proper amount of fuel is loaded by accurately managing fuel based on the potential risk factors by the destination airport. Loading of excessive discretionary fuel can cost airlines huge amount per year and produce additional carbon emissions.

Airlines will benefit from this study by using the results as a practical guideline for loading proper amount of discretionary fuel, which in turn minimizes the unnecessary fuel cost.

There is no accurate study on actual fuel consumption and the appropriate amount of discretionary fuels owing to the difficulty in collecting data on aircraft operations. Preliminary researches have analyzed the fuel savings effect using a database formatted according to aircraft type and suggested a method to improve fuel efficiency. However, fuel consumption of an aircraft depends on various factors, such as the thrust of the engine, seat capacity, en route weather condition, cruising altitude, speed, and flight distance.

This study shows that airlines will benefit by reducing fuel cost with historical data on discretionary fuel. If we consider this simulation modeling for discretionary fuel, airlines will be able to reduce 5,063.6 tons of $\mathrm{CO}_{2}$ and save USD 207,845 every year.

This determining the amount of discretionary fuel can be optimized using advanced technologies and sophisticated predictive tools for data analytics and decision support. There are some difficulties in figuring out evaluating of various probability distributions.

In addition to the economic and environmental benefits, airlines will be able to minimize the risk of unplanned flight disruptions caused by insufficient fuel on board.

Although the objectives of the study were

4) https://www.transtats.bts.gov/fuel.asp 
achieved, there are some limitations to use adverse weather factors such as fog, snow, and severe thunderstorm in the departure and destination airport. These are the critical factors when dispatchers decide the amount of discretionary fuel and it will affect actual fuel consumption for flight operations.

Future researchers should be encouraged to determine the appropriate amount of discretionary fuel by more detailed analysis on the big data of the actual fuel consumption by subdividing the adverse weather conditions and forecasts at the departure and destination airports.

\section{References}

1. International Air Transport Association (IATA), "Guidance material and best practices for fuel and environmental management", International Air Transport Association, 2011, pp.83-84.

2. International Civil Aviation Organization(ICAO) Doc. 9976 "Flight Planning and Fuel Management Manual”, 2012, pp.4-26.

3. Altus, S., "Effective Flight Plans Can Help Airlines Economize”, Boeing, 2009.

4. Dorneich, M, C., Olofinboba, O., Pratt, S., Osborne, D., and Feyereisen, T., "Evaluation of a Dispatcher's Route Optimization Decision Aid to Avoid Aviation Weather Hazards", NASA Langley Research Center, Hampton Virginia, 2003, pp.43-45.

5. Karisch, S., Altus, S., and StojkovićGand, S., "Operations quantitative problem solving methods in the airline industry", A Modeling Methodology Handbook series. International Series in Operations Research and Management Science, 2012, pp.283-384.

6. Nash, B., "A simplified alternative to current airline fuel allocation modes", Informs Journal on Applied Analytics, 11, The Institute of Management Sciences, 1981, pp. 1-9.

7. Kang, L., "Changing fuel loading behavior to improve airline fuel efficiency", University of California, Berkeley, 2017, pp.7-8.

8. Jensen, L. L., Tran, H., and Hansman, R. J., "Cruise Fuel Reduction Potential from Altitude and Speed Optimization in Global Airline Operations", 11th USA/Europe Air Traffic Management Research and Development Seminar, 2015, pp.1-10.

9. Edwards, H. A., Dixon-Hardy, D., and Wadud, Z., "Aircraft cost index and the future of carbon emissions from air travel”, Applied Energy, 164, 2016, pp.553-562.

10. Ryerson, M. S., Hansen, M., and Hao, L., "Landing on empty: Estimating the benefits from reducing fuel uplift in U.S. civil aviation”, Environmental Research Letter, 10(9), 2015, pp.1689-1699.

11. Wasiuk, D. K., Lowenberg, M. H., and Shallcross, D. E., "An aircraft performance model implementation for the estimation of global and regional commercial aviation fuel burn and emissions" Transportation Research Part D: Transport and Environment, 35, 2015, pp.142-159.

12. Pagoni, I., and Psaraki-Kalouptsidi, V., "Calculation of aircraft fuel consumption and $\mathrm{CO}_{2}$ emissions based on path profile estimation by clustering and registration", Transportation Research Part D: Transport and Environment, 54, 2017, pp.172-190.

13. Dagpunar, J. S., "Simulation and Monte Carlo with Applications in Finance and MCMC", John Wiley \& Sons Inc, 2007, pp.157-186.

14. Kroese, D. P., Thomas, T., and I., B. Z., "Handbook of Monte Carlo Methods", John Wiley \& Sons, Inc. 2011, pp.85-152.

15. Irvine, D., Budd, L. C. S., and Pitfield, D. E., "A Monte-Carlo approach to estimating the effects of selected airport capacity options in London", Journal of Air Transport Management, 42, 2015, pp.1-9.

16. Pitfield, D. E., and Jerrard, E. A., "Monte Carlo comes to Rome: A note on the estima- 
tion of unconstrained runway capacity at Rome Fiumicino International Airport", Journal of Air Transport Management, 5(4), 1999, pp.185-192.

17. Stroeve, S. H., Blom, H. A. P., and (Bert) Bakker, G. J., "Systemic accident risk assessment in air traffic by Monte Carlo simulation”, Safety Science, 47(2), 2009, pp.238-
249.

18. Peat J., and Barton B., "Medical Statistics: A Guide to Data Analysis and Critical Appraisal", Blackwell Publishing, 2008, pp.24-50.

19. Filippone, A., "Comprehensive analysis of transport aircraft flight performance", Progress in Aerospace Sciences, 44(3), 2008, pp.192-236. 